Корнелија Ичин

Универзитет у Београду

Филолошки факултет

Катедра за славистику

kornelijaicin@gmail.com
УДК 821.161.1.09:929 Ћурић, Б. https://doi.org/10.18485/slavistika.2020.24.1.1 примљено 31.03.2020. прихваћено за штампу 21.05.2020.

\title{
БОБАН ЋУРИЋ - ЧОВЕК С КЊИГОМ
}

За оне који мисле да човека можемо дефинисати временом и простором: рођен је 13. децембра 1968. године у Ћуприји, преминуо - 13. септембра 2019. у Београду.

Тачка.

Живот Бобана Ћурића је енергија стицања знања, чување памћења, несебично давање стеченог духовног богатства нашој заједници. Живот са књигом и мапом, корачање кроз време на балканским и европским просторима, радост откривања скривене лепоте у крхотинама прошлости - то је Бобан Ћурић.

Заљубљеник у митове, религију, историју, географију, урбанистичке планове, архитектуру, успео је да кроз проучавање руске књижевности оствари свој сан - постане човек енциклопедијског знања којим је ненаметљиво умео да задиви младе људе у слушаоници славистичког семинара и покрене њихов дух у потрази за непознатим световима.

Ћупријски гимназијалац, одликаш, носилац Вукове дипломе, упутио се и за себе помало неочекивано на студије руског језика и књижевности у Београду, не слутећи да ће Филолошки факултет и град Београд постати његова друга кућа. Љубав према граду као месту културе и науке, спремност да стиче знања у сваком тренутку живота учинили су да Бобан Ћурић током студија израсте у младића који се издвајао својом наочитошћу. Тако је скренуо пажњу двојице професора који су били заинтересовани да га имају за сарадника: проф. др Александра Терзића - за руску фонетику и проф. др Миливоја Јовановића - за руску књижевност.

Али одлука је одавно била донесена: бриљантни успех на основним студијама био је овенчан изузетним дипломским радом на тему која га никада није напуштала у тумачењу књижевног текста: о библијским мотивима у руској књижевности (на примеру приповедака Лава Лунца). Овој тематици Бобан Ћурић ће се с посебним жаром вратити након двадесет година у својој докторској дисертацији „Романи Бориса Савинкова (В. Ропшина)“, одбрањеној 2013. године. Понирући у филозофско-историјске дубине Савинковљевих романа, откривајући главну „идеју“ овог контроверзног писца кроз књижевно и идеолошко наслеђе руског XIX века те „нову религиозну свест“ Сребрног доба, Бобан Ћурић се најдуже задржавао на митопоетско-библијском нивоу стваралаштва руског писца. Посматрајући животни и научни пут Бобана Ћурића са ове дистанце можемо рећи да је Библија била његова водиља у поимању живог живота и стваралачког чина. Њоме је проверавао многе поступке људи, али и уметничке замисли писаца. И сам је попут библијских 
јунака био „осуђен“ на вечито кретање, савладавање земаљских растојања, мерење простора корацима.

Из размишљања о лутањима изабраног народа у потрази за „обећаном земљом“ родиће се у Бобану Ћурићу интересовање за руску емиграцију - прогнану, отуђену од родне груде, посвећену умом и срцем изгубљеном рају царске Русије. Занимање за руске изгнанике појавиће се већ приликом израде магистарског рада „Руска књижевност у београдском дневном листу Правда. 1917-1941“ (одбрањен 2000. године), где ће се бавити рецепцијом не само руске класике XIX века у нашим дневним новинама, већ и књижевног опуса руских аутора у расејању, укључујући и њихова издања у Југославији. Нема сумње, највише је времена и труда уложио Бобан Ћурић у проучавање феномена руске емиграције што је и резултирало књигом „Из живота руског Београда“, насталом у оквиру научног пројекта „Кодови руске културе“ (2011). Превод књиге на руски језик објавио је 2015. године Филолошки факултет за потребе презентације наших научних достигнућа на Међународном сајму књига у Москви. Ова књига Бобана Ћурића била је веома запажена у руској научној јавности - доживела је презентације у московском Дому руске дијаспоре, као и на Универзитету у Нижњем Новгороду. Базирана пре свега на периодичким написима о руским историјским, књижевним и културним личностима, она је тек мали део онога што је проучавао и знао Бобан Ћурић о руској емиграцији. Његов opus magnum о животу руске емиграције на нашим просторима требало је да уследи у годинама које су долазиле, како смо мислили... Ипак, студенти из Бањалуке, где је Бобан Ћурић био гостујући професор, са најдубљом захвалношћу и осећањем дуга за подарено знање, као прави мали фјодоровци, чувари памћења, приредили су његова предавања из специјалног курса који је водио и објавили их као књигу под називом „Руска емиграција““ (2019), намењену за поклон свим заинтересованим читаоцима.

Радећи на Филолошком факултету у Београду од 1995. године у звањима од асистента приправника до ванредног професора, Бобан Ћурић је на чудесан начин остајао исти - пун ентузијазма у раду са студентима, енергичан, посвећен, неуморан у подстицању на размишљање, неприкосновен у буђењу радозналости у младом нараштају, до краја предан у настојању да пренесе знања из богате руске књижевне и културно-историјске традиције. Нимало није случајно што су га студенти толико волели, највише од свих наставника на Катедри за славистику. А могли су да га слушају на различитим предметима из руске књижевности и културе на првој, трећој, четвртој и петој години студија, као и ван наставе на јавним наступима у Коларчевој задужбини или Руском дому, на екскурзијама по ,руском“ Београду.

Дечачки сан да постане туристички водич (о чему је говорио и Борису Успенском у Београду) нашао је одраза у походима које је Бобан Ћурић организовао кроз Београд и Србију заједно са студентима, али исто тако и са страним научницима, гостима Катедре за славистику, остављајући без даха како највеће слависте, тако и слависте-почетнике својом ерудицијом и љубављу према свему ономе што је људски дух оставио у наслеђе нама на Балкану.

Лаки Бобанов корак праћен жустром гестикулацијом руку и главе, убедљивим јасним и звучним гласом, оживљавао је историјске прилике, подизање 
здања, осликавање зидова манастира, новинске расправе, пријеме код краља Александра Карађорђевића. Спој кретања кроз простор и време са заустављеним тренутком из ближе или даље историје осетио је свако ко је нетремице слушао, примао и маштолико пребивао у другој епохи, коју је дочаравао Бобан Ћурић.

Научни и стручни рад, оличен у различитим публикацијама (монографија „Из живота руског Београда“, 50-ак студија, 10 стручних текстова), учешћу на домаћим и међународним конференцијама (Русија, Бугарска), предавањима по позиву (Нижњи Новгород), бројним бриљантним књижевним преводима, организовању научних скупова, раду у телима Филолошког факултета био је само део јавног живота Бобана Ћурића. Међутим, његова највећа страст биле су књиге и путовања, читање и визуелизација прочитаног, спој фиктивног и опипљивог. Одсуство нагона за поседовањем било каквих материјалних добара било је у апсолутној пропорционалној супротности са стеченим знањем у овом скромном и благом човеку.

Одлазак Бобана Ћурића све је подсетио на речи великог Булгакова - да је човек не само смртан него понекад изненада смртан. Ово „изненада“ изван граница логике, које говори о рушењу устаљеног поретка ствари, остало је као опомена да смо тек накратко гости у овоме свету и да немамо мерну јединицу за живот. Пређени пут Бобана Ћурића између „експлозија“ рођења и смрти, двају преображаја који се спајају у тачки почетка и краја, буђења и сна, живог и неживог, могао би се мерити памћењем студената који ће преносити на будућу младост све оно што су од њега научили, а ови на следеће поколење и следеће на следеће... Јер једино захваљујући памћењу смртни постају бесмртни. 